\title{
イントラムロス（マニラ）の形成と街路体系に関する考察 CONSIDERATIONS ON FORMATION AND STREET SYSTEM OF INTRAMUROS (MANILA)
}

\author{
塩田哲也*，J.R. ヒメネスベルデホ**，布野修司***
} Tetsuya SHIODA, Juan Ramón JIMÉNEZ VERDEJO and Shuji FUNO

\begin{abstract}
Authors have been conducting the field research on the former Spanish colonial cities under the title 'Origin, Transformation, Alteration and Conservation of Urban Space of Colonial Cities since 1999. In the Spanish colonial period, cities were planted and established in Philippines. This paper focuses on Intramuros, the historic walled area of Manila city which is one of the three city established by Spain in Asia. As cartographic database, images and maps from AGI (Archivo de Indias de Sevilla), other archives and libraries in the Philippines are used for analysis.

This paper clarifies the formation and transformation process of Intramuros based on the analysis of historical maps and street pattern and block size, also the present formation of urban core of the city based on the field survey on the distribution of facilities and building types.
\end{abstract}

Keywords : Intramuros, Manila, Spanish colonial, Grid, Street system, Urban tissues イントラムロス, マニラ, スペイン植民都市, グリッド, 街路体系, 都市組織

\section{1. はじめに}

本研究は,「植民都市空間の起源・変容・転成・保全に関する調查 研究」と題する植民都市研究の一環として, スペイン植民都市を対 象とし，その拡大深化を図ることを大きな目的としている。本研究 の遂行過程で, セビーリヤ Sevilla のインディアス古文書館 (Archivo General de Indias (AGI) ) に収蔵された植民都市関連地 図資料全 7,152 枚をマイクロフィルムの形で, またマドリード Madrid にある陸軍博物館資料 Servicio Histórico Militar（SHM） と Servicio Geográfico del Ejercito（SGE）の地図資料全 1514 枚 (全 10 巻) を手に入れている注 1 )。

本稿では，フィリピンの首都マニラ Manila の都市核であるイン トラムロス Intramuros に焦点を当てる。古地図をもとにマニラの 都市形成についてまとめた上で, 臨地調査に基づいて, 現状の施設 分布等を明らかにし, 街路体系, 街区構成, そして敷地割りを中心 にその特質を明らかにする。スペイン植民都市として建設されたセ ブ注 2)やヴィガン注 3)なども含めて, 他のスペイン植民都市との比較 が大きな視点となる。

マニラは，セブ，パナイに続きミゲル・ロペス・デ・レガスピ

Miguel López de Legazpi によって, 建設された 3 番目の都市であ

る。イントラムロス (イントラ=内側，ムロス=壁）はその名の通り， 城壁で囲まれた都市である。

主要参考文献は末尾に示寸通りであるが，マニラに関する既往研 究は決して多くは無い。フィリピンにおけるスペイン植民都市の概 要とイントラムロスの都市形成を一覧にしたリード Reed, Robert
R. (1978) の論文がある。その他にも Galván Guijo, Javier（2004） やOrtiz Armengol, Pedro（1958）があり，都市形成に関する資料 はいくつかある。イントラムロス内に建設された建物についてまと めたテレス Victor Z. Torres, José（2005）もある。また，1595 年 から 1603 年までフィリピン副総督に着任したモルガ de Morga, Antonio が書いた『フィリピン諸島誌 Sucesos de las Islas Filipinas』(1609) がある。

本研究の基となる現地調查は，2009 年 9 月 11 日〜2009 年 9 月 24 日（布野修司， J.R ヒメネス・ベ ルデホ, 飯田敏史, 若松堅太郎）, 2010 年 7 月 31 日 ～ 2010 年 8 月 13 日（J.R ヒメネ ス・ベルデホ，塩 田哲也, 山口健太, 山田聖)，2011 年 11 月 2 日 2011 年 11 月 9 日 (J.R ヒメネス・ベルデ ホ，梅谷敬三，平 沢陽）の三次にわ たって行なった。

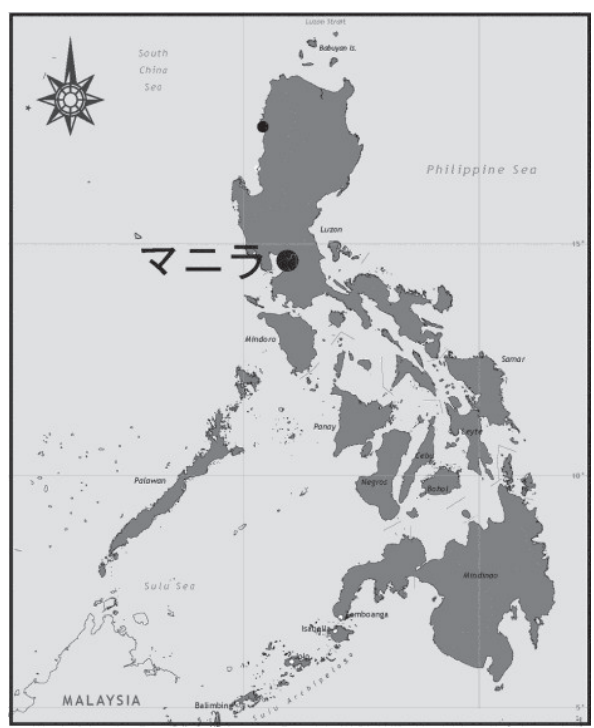

図 1 マニラとフィリピン諸島
Tohyoh Construction Co., Ltd., Master (Environmental Science)

Assoc. Prof., Graduate School of Environmental Planning, University of Shiga Prefecture, Ph. D.

Prof., Graduate School of Environmental Planning, University of Shiga Prefecture, Dr. Eng. 


\section{2.マニラの地図資料}

フィリピン植民都市関連地図資料に関しては，セビージャのイン ディアス古文書館 AGI に 299 枚（内,マニラ 105 枚）ある。マドリ ードMadrid の陸軍博物館資料 SGE/SHM に 140 枚（内,マニラ 43 枚）ある。その他に，作成者は不明であるが，メキシコのプエブラ Puebla にあるホセ・ルイス・ベロー美術館 Museo de Arte José Luis Bello に所蔵される，1640 年から 1650 年にかけてのマニラを描い たとされる絵図, ヴァヤドリード Valladolid のシアマンカス古文書 館 Archivo General de Siamancas (AGS)に所蔵される地図, アン トニオ・フェルナンデス・ロハス Antonio Fernández Rojas によっ て 1715 年から 1720 年にかけて描かれたとされる絵図, ヴァルデ ス・タモン Valdés Tamón の時代（1729-1739）の都市図（1738）, アメリカ統治期に建築家ダニエル・ハドソン・バーナム Daniel Hudson Burnham 注4)の都市計画図がある。

これらの地図は,「スペイン植民都市図に見る都市モデル類型に関 する考察」注5)によれば, A一般地図, B 軍事用地図, C 領域計画図, $\mathrm{D}$ 都市一般図, $\mathrm{E}$ 都市計画図, $\mathrm{F}$ 建築計画図, G 都市建築要素の詳 細図, $\mathrm{H}$ その他の 8 種に分類される。マニラのイントラムロスにつ いては要塞に関する図面資料は多く, $\mathrm{F}$ 建築計画図を, F-1一般建 築計画図 (教会, 各種施設, 住居など) と F-2 要塞図（要塞，市壁， 門, 塔など) に分けると,マニラに関する地図類は, D 都市一般図 (42 枚), $\mathrm{E}$ 都市計画図 (6 枚)，F-1 一般建築計画図 (39 枚)， F-2 要塞 困（66 枚）となる。 D 都市一般図と $\mathrm{E}$ 都市計画図の合計 48 枚を, 「都市図 I」(イントラムロスのみ街区構成が描かれた都市図)，「都 市図 II」(イントラムロスも周囲の町も街区が描かれている都市図)，

「都市図III」(イントラムロスが描かれず，もしくは一部のみで，周 辺の町の街区が描かれた都市図) の 3 つの項目に分けて,表 1 に示す 注 6)。

\section{3. イントラムロスの建設過程}

地図資料と諸文献等をもとに，イントラムロス内に建設された建 物の年代に着目し，イントラムロスの建設過程とその変容をまとめ ると以下のようになる。主要な段階の地図を図 2 に,また,以下の $\mathrm{A}$ 〜 I に対応したイントラ ムロスの構成を GIS デ ータをベースマップとし て図 3 に示す。

A マニラのイントラ ムロスは, バイ湖 Laguna de Bay からマ ニラ湾 Manila Bay に注 いでいるパシグ川 Rio de Pasig の汇濫により土砂 が堆積して形成された三 角州に位置する。10 世紀 ごろには居住が認められ バランガイ Barangay(タ ガログ語は Baranggay, 集落, 共同体) が形成さ れ,農耕や狩り漁業を営
み，中国や東南アジアと交易を行っていたとされる。13 世紀から 16 世紀にかけて，バランガイは,ラカン Lakan あるいはラージャ Rajahs, ダトゥと呼ばれる王や首長によって統一され,パシグ川河口

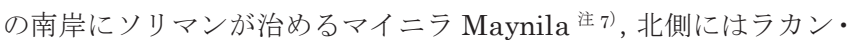
ドゥーラ Lakan Dula が治めるトンドTondo と呼ばれる集団があり 港市として栄えていた（Reed, Robert R.(1978))。

B 1571 年, 中央広場 Plaza Mayor となる場所に木の幹を埋め, 上陸の記念式典が行われた。この広場の南に教会 (マニラ大聖堂), 東に市庁舎 Casas de Cavildo, 西に総督邸 Real Palacio を割り当て た。当初，総督邸はソリマン期の砦の中に建設されたが，1645 年に 起きた地震によりこの地に移された（de Morga, Antonio(1609)）。

C 初期のマニラは木造であった。1574 年中国人海賊林鳳による マニラへの攻撃を受け, 総督ラベサレス Guido de Labezares (1572 -1575）は，木の柵でマニラを囲む計画をする。次の総督サンデ Francisco de Sande（1575-1580）の時代に完成し，カバイェロス Caballeros と呼ばれる木造の見張り台も建設された。ロンキヨ Gonzalo Ronquillo de Peñalosa 総督期（1580-1583）に，中国人居 住地パリアン注 8)が創設される(1582)。1583 年ロンキリョの死後, サン・アウグスティン教会 San Agustín Church で葬式中に出火し, マニラは焼け落ちた（de Morga, Antonio(1609)）。

D 1584 年に総督に即位したベラ Santiago de Vera (1584-1590) は,マニラの大火災を受け, 石造化を命じた。最古の石造建築物は, イエズス会士アントニオ・セデーニョによるサン・イグナシオ教会 San Ygnacio Church であった。沿岸部にヌエストラ・セニョーラ・ デ・ギア要塞 Fort Nuestra Señora de Guía（1586）も建設してい る。またパッシグ川河口にあった木造の砦は石造化され, サンティ アゴ要塞 Fort Santiago（1589 -1592）と名付けられた。次総督で あるゴメス・ペレス・ダスマリニャス Gómez Pérez Dasmariñas (1590 -1593) と息子のルイス・ペレス・ダスマリニャス Luis Pérez Dasmariñas（1593-1596）期に，木の柵も石造の城壁へと再建され る（レオナルド・トリアノの計画）。ヌエストラ・セニョーラ・デ・ ギア要塞もサン・ディエゴ要塞に再建される（de Morga, Antonio(1609))。

\begin{tabular}{|c|c|c|c|c|c|c|c|}
\hline$X$ & 地図コード & 地図年代 & 地図の分類 & 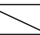 & 地図コード & 地図年代 & 地図の分類 \\
\hline 1 & MP-FILIPINAS, 10 & 1671 & 都市一般図/都市図 I & 23 & AGI,MP-FILIPINAS, 131 & $1796-06-28$ & 都市一般図/都市図 II \\
\hline 2 & AGS & 1685-1687 & 都市一般図/都市図 II & 24 & AGI,MP-FILIPINAS, 189 & $1796-12-31$ & 都市一般図/都市図 II \\
\hline 3 & Antonio Fernández Rojaz & $1715-1720$ & 都市一般図/都市図 II & 25 & SH 6499 (Hoja 1) & 1799 & 都市一般図/都市図 II \\
\hline 4 & Valdés Tamón & 1738 & 都市一般図/都市図 II & 26 & SGE Q-1-3-87 & 1802 & 都市一般図/都市図 II \\
\hline 5 & AGI,MP-FILIPINAS, 31 & 1746-05-14 & 都市一般図/都市図III & 27 & SH 7414 & 1806 & 都市一般図/都市図III \\
\hline 6 & AGI,MP-FILIPINAS, 42 & 1763-07-29 & 都市一般図/都市図 II & 28 & AGI,MP-FILIPINAS,191 & 1814-01-03 & 都市一般図/都市図吕 \\
\hline 7 & AGI,MP-FILIPINAS, 43 & 1764-01-04 & 都市一般図/都市図 II & 29 & AGI,MP-FILIPINAS, 133 & 1814-01-04 & 都市一般図/都市図 II \\
\hline 8 & AGI,MP-FILIPINAS, 160 & 1764-07-12 & 都市計画図/都市図 II & 30 & SH 6521 & 1814 & 都市一般図/都市図 II \\
\hline 9 & SH 6676 (Hoja 16) & 1766 & 都市一般図/都市図III & 31 & SH 6658 & 1831 & 都市一般図/都市図 II \\
\hline 10 & SH 6520 (Hoja 3) & 1767 & 都市一般図/都市図 II & 32 & SH 13878 (Hoja 1) & 1831 & 都市一般図/都市図III \\
\hline 11 & AGI,MP-FILIPINAS, 51 & 1767-09-30 & 都市一般図/都市図 II & 33 & SH 13975 (Hoja 2) & 1831 & 都市一般図/都市図III \\
\hline 12 & AGI,MP-FILIPINAS, 63 & 1770 & 都市一般図/都市図 II & 34 & SH 13993(Hoja 2) & 1831 & 都市一般図/都市図吕 \\
\hline 13 & AGI,MP-FILIPINAS,232 & $1771-12-15$ & 都市計画図/都市図 II & 35 & SH 13966 (Hoja 3) & 1834 & 都市一般図/都市図 II \\
\hline 14 & AGI,MP-FILIPINAS, 72 & 1772-07-01 & 都市計画図/都市図 II & 36 & SH 13955 & 1838 & 都市一般図/都市図III \\
\hline 15 & SGE Q-1-3-65 & 1777 & 都市一般図/都市図 II & 37 & SH 6685 & 1842 & 都市一般図/都市図 II \\
\hline 16 & AGI,MP-FILIPINAS,93 & 1779 & 都市一般図/都市図 II & 38 & SH 6502 & 1843 & 都市計画図/都市図III \\
\hline 17 & AGI,MP-FILIPINAS,229 & 1783-06-26 & 都市一般図/都市図 $I$, 宅地 & 39 & SH 6659 & 1859 & 都市一般図/都市図III \\
\hline 18 & SH 6583 (Hoja 1) & 1784 & 都市一般図/都市図 II & 40 & SGE Q-1-3-94 & 1898 & 都市一般図/都市図 I \\
\hline 19 & AGI,MP-FILIPINAS, 123 & $1785-05-31$ & 都市一般図/都市図 II & 41 & Daniel Hudson Burnham & 1904 & 都市計画図/都市図 II \\
\hline 20 & SH 6676 (Hoja 6) & 1785 & 都市一般図/都市図 II & 42 & SGE Q-1-3-66 & $1780 ?$ & 都市一般図/都市図 II \\
\hline 21 & AGI,MP-FILIPINAS, 185 & $1793-05-12$ & 都市計画図/都市図 II & 43 & SH7316 & $18--?$ & 都市一般図/都市図 II \\
\hline 22 & AGI,MP-FILIPINAS, 188 & $1795-12-23$ & 都市一般図/都市図 II & & & & \\
\hline
\end{tabular}




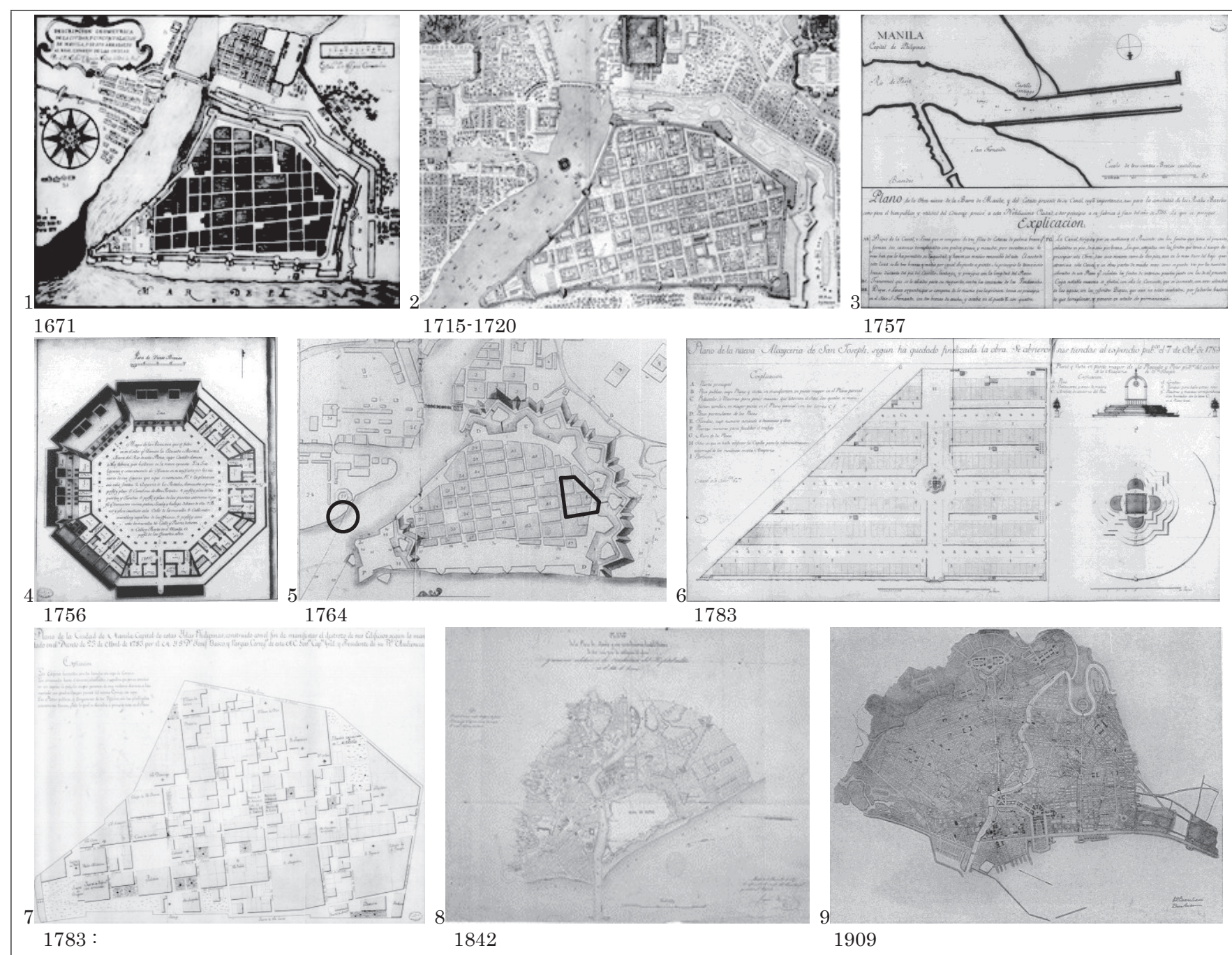

図 2 マニラの歴史地図

1:1671, AGI,MP-Filipinas.10. 2: Antonio Fernández Rojas, 1715-1720. 3:1757, AGI,MP-Filipinas.40. 4: 1756, AGI,MP-Filipinas.38 . 5:1764, AGI,MP-Filipinas.160. 6:1783, AGI,MP-Filipinas,225. 7:1783, AGI,MP-Filipinas,229. 8:1842, SH 6685. 9: Manila Master Plan, Daniel Hudson Burnham, 1904 from Plan of Chicago, the Commercial Club, 1909.

$\mathrm{E}$ マニラの城塞化が完成すると, 1603 年からは, 城壁の外側に 堀を築く計画が行われる。同時に, 城壁にサン・アンドレス要塞 Baluarte de San Andrés (1603), パリアン要塞 Revellín del Parian (1603), サンタ・イザベル要塞 Baluarte de Santa Isabel （1609-1632）が建設され, 軍事面での強化が図られた。1611 年に は, 現在アジアで最も古い大学であるサント・トマス大学が建設さ れる。パッシグ川には, 1623 年にエスパーニャ橋 Puente de España が架けられ，同時に，橋門プリンシパル門 Puente Principal もつく られた。1 671 年の都市図でイントラムロスの完成が確認できる。こ の時までに, 54 街区, 城壁には 5 つの門が設置された（図 2-1） (Galván Guijo, Javier(2004))。

F 1718 年にはサンチャゴ要塞に堀が造られ, 独立する (図 2-2)。 1757 年には, パッシグ川の護岸工事が開始され, 北部トンド地区は 海岸線の埋め立てが始まる (図 2-3)。また八角形のパリアンの市場 である Real Alcaicería de San Fernando は，1754 年に建設された (図 2-4)。1756 年から始まる英仏七年戦争に加戦したためイギリ スは, スペイン植民地にも攻撃し, マニラも同様に被害を受け, 占 領される。1763 年のパリ条約で七年戦争が終結し, スペインに返還
されると, さらなる軍事強化のため都市改造計画が行われる（図 2-5)。イントラムロスの街区構成は, 1671 年の都市図以降ほとんど 変化することはないが, 1784 年には, アルカイセリア・デ・サン・ ホセ Alcaicería de San José と呼ばれる中国人市場が建設されるこ とで街区が変化する（図 2-6）。また 1770 年以降の都市図から, 広 場が拡大している。唯一宅地が描かれている都市図は 1783 年に描 かれた（図 2-7）(Galván Guijo, Javier(2004))。

G パリアンは, 1860 年に廃止され, 北部ビノンド等に移される。 サン・ガブリエル地域は公園として整備された。1 818 年には, パコ・ パーク (墓) が建設され, パッシグ川には, 第 2 のケソン Quezon 橋も架けられた。フランス革命（1789）以降, スペイン植民都市で 独立運動が相次ぐ。米西戦争の結果, スペインの統治は, セブの植 民地支配から 333 年が経った 1898 年で幕を閉じる（図 2-8）。

H アメリカ時代になると, アメリカ軍による評議会は, 1904 年 までにパッシグ川沿いの城壁を取り壊し, 完全に取り壊すことを決 めていた。しかし, マニラの都市計画を行った建築家バーナムによ ってイントラムロスは守られる。バーナムは, 城壁など, 中世の防 御システムの遺産として価值を評価し, イントラムロスの都市構造 


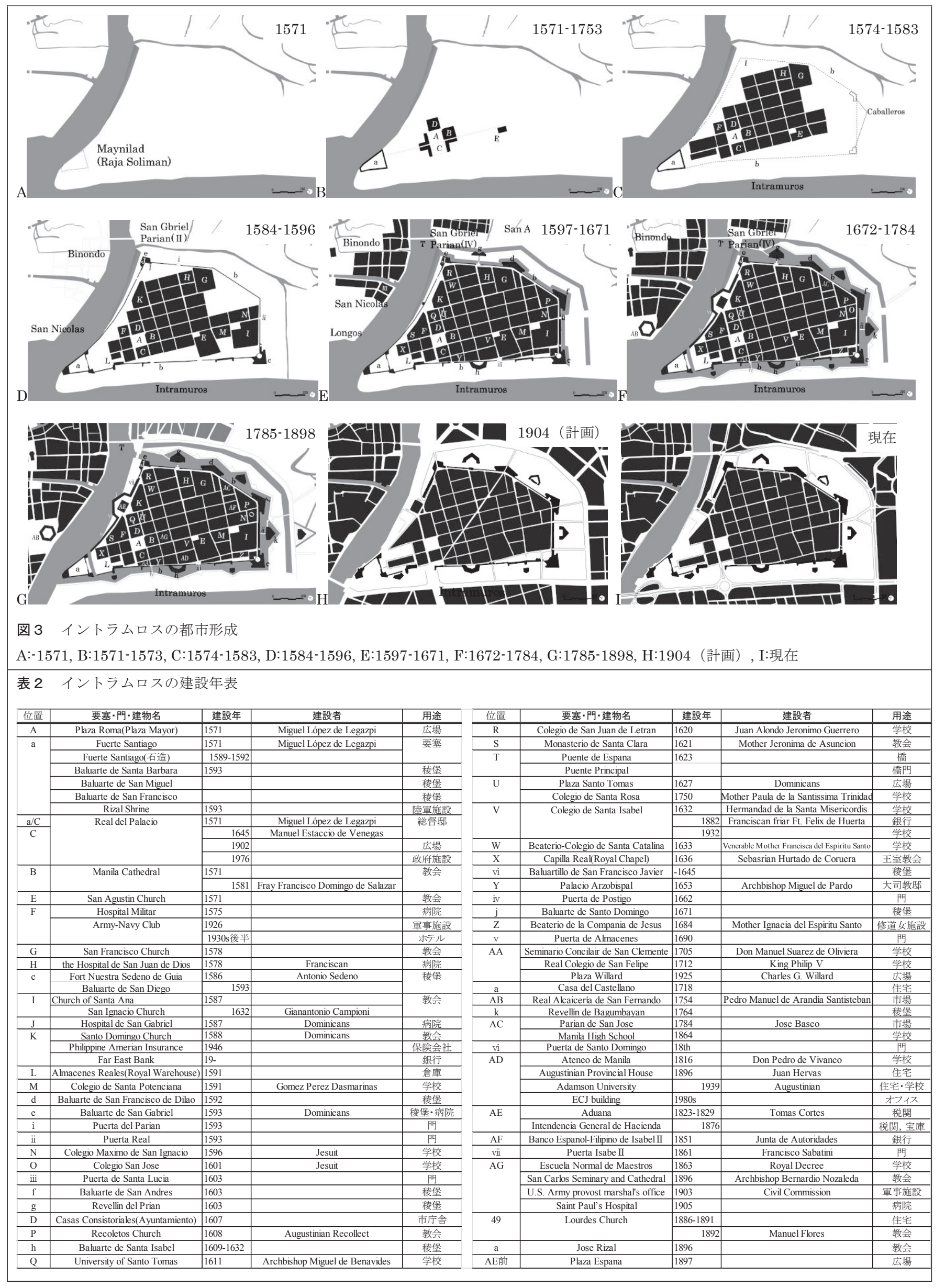


を保存した。バーナムによる都市計画は，実際はあ まり計画通りに建設されなかったが，トンド，ビノ ンド地区など, パッシグ川より北部の地域でその街 区形状が見られる（図 2-9）。1934 年にアメリカ合 衆国議会のタイディング・マクダフィー法設置によ り,フィリピンは 10 年後の完全独立を約束される。 しかしその前の 1941 年 12 月 8 日には太平洋戦争が 勃発, 日本軍はフィリピン侵略を開始する。1942 年 1 月 2 日には首都マニラに進行し, 翌日には軍政 を開始した。これ以降 1945 年 8 月の終戦までフィ リピンは 3 年 8 カ月に及ぶ日本の占領支配を受け, この間にマニラを中心にアメリカからの攻撃を受け 続け, 壊滅的な被害を受ける。

I 1951 年にエルピディオ・キリノ Elpidio Quirino 大統領によってイントラムロスを修復する ことが注目され，1966 年アレハンドロ・ロセス Alejandro Roces を議長とするイントラムロス復興 委員会 Intramuros Restoration Committee(IRC)が 設立, 一部の城壁と 6 つの門, サンチャゴ要塞が修 復された。1979 年には, フェルディナンド・マルコ ス Ferdinand Marcos 大統領は，イントラムロス管 理局（IA）を設立，法律を制定し管理した。イントラ ムロス管理局は, イントラムロスの監視と維持, 修 復, 管理を主な責務としている。現在城壁はパッシ グ川部分を除き再建された。イントラムロス管理局 は, イントラムロスのみに範囲をとどめず, その他 のヴィガンやイロコス, ネグロスなどルソン島全域 を管轄するようになっている。

復興もこれまでの街区構成を採用し, 現在に至る まで街区構成はほとんど変化していないことが特徴 である。

\section{4. イントラムロスの空間構成 \\ 4-1 建築物の分布}

GIS データによると, 現在イントラムロス内には, 街区が 54, 建築物は 746 棟ある。臨地調查によって 確認できなかった建物が 219 棟あるが,そのほとん ど（135 棟）はひとつの街区（図 6 の 20）の建物で ある。いわゆる「あんこ」の部分に建物が密集して おり,個々の建物の用途を確認できなかったもので ある。全て専用住宅もしくは店舗併用住宅と考えら れる。もうひとつ小規模住居が密集する街区（図 6 の 25）があるが,同様に専用住宅もしくは店舗併用住宅である。そ れらは不明とするが, 全体の分布傾向は把握できる。建築物の構造, 用途,階数を示すと図 4 のようになる。

伝統的な住居形式であるバハイ・ナ・バド注 9) は存在せず, $\mathrm{RC}$ 造 がほとんどである (329 棟)。その他に木造 98 棟，木造十コンクリ 一ト造 25 棟, 石造 12 棟, ブロック造 11 棟などが確認できた。専 用住居 144 棟, 店舗併用住居 113 棟, 商業施設 113 棟, 教育施設 43 棟, 工場・倉庫・ガレージ 36 棟, 政府関連施設 27 棟, 公共施

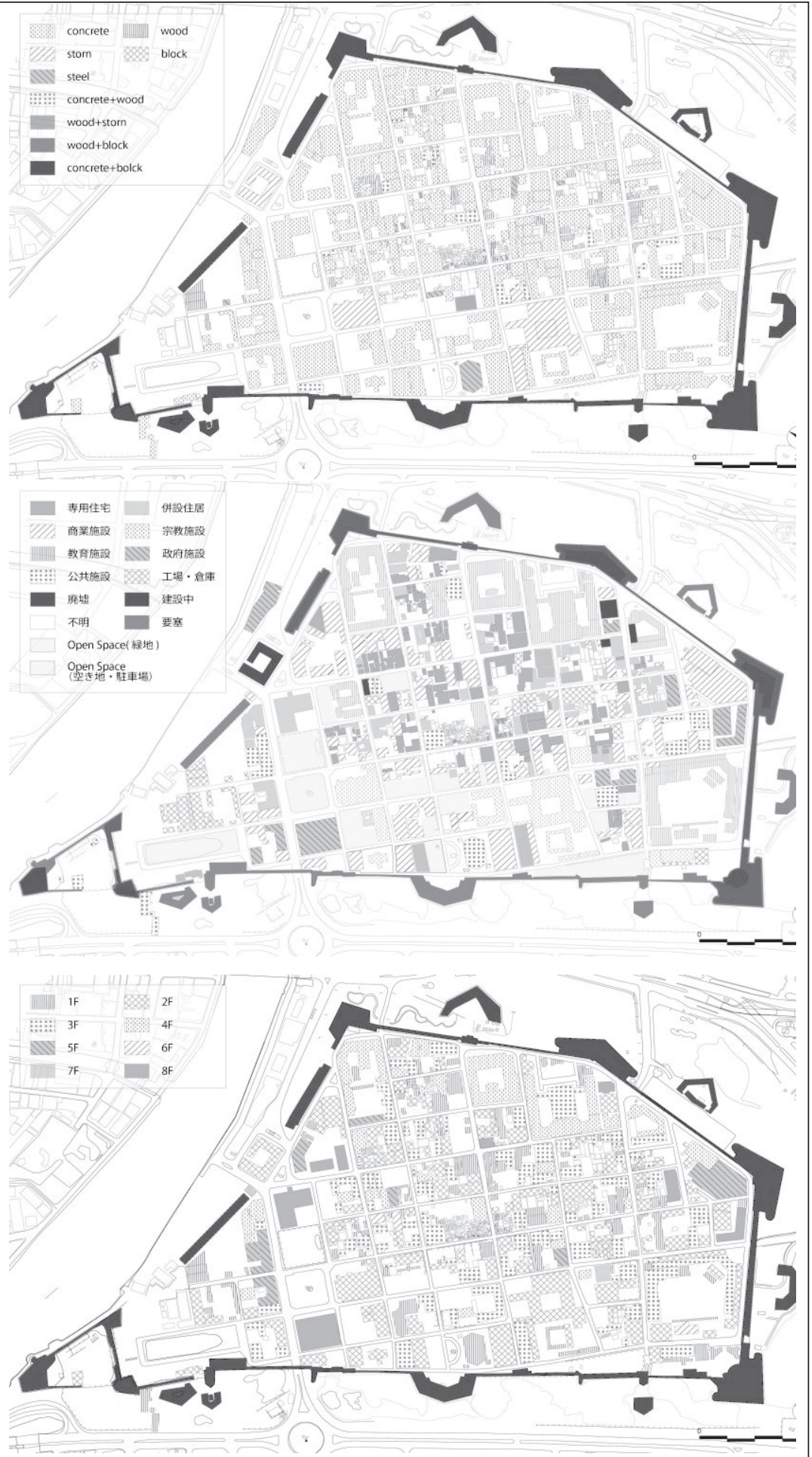

図 4 構造分布 (上), 施設分布 (中), 階数分布 (下) 
られている。総督邸や大司教邸などの建設記録を 除いて個人住宅などの建設年はほとんど不明であ るが,建設当初から住宅地はイントラムロスの中 央部に配置されていたと考えられる。

教会は, 20 世紀初頭, 第 2 次世界大戦までは, スペイン統治期と変わらず 7 つの教会（マニラ大 聖堂, サン・アウグスティン教会, サン・フラン シスコ教会, サン・イグナシオ教会, サント・ド ミンゴ会, リコレクトス教会) があった。現在は, マニラ大聖堂とサン・アウグスティン教会のみが 残っている。

教会の跡地には, 学校が建てられていることが 多い。イントラムロスの学校として, スペイン統 治期からそのまま存在するものに, サント・トマ ス大学 (戦後にキアポ郊外一移動) サン・フアン・ デ・レトラン大学, サンタ・ロサ大学, マニラ高 校がある。戦後の教会跡地に建設された学校に, アプア工科大学 (サン・フランシス教会跡), マニ

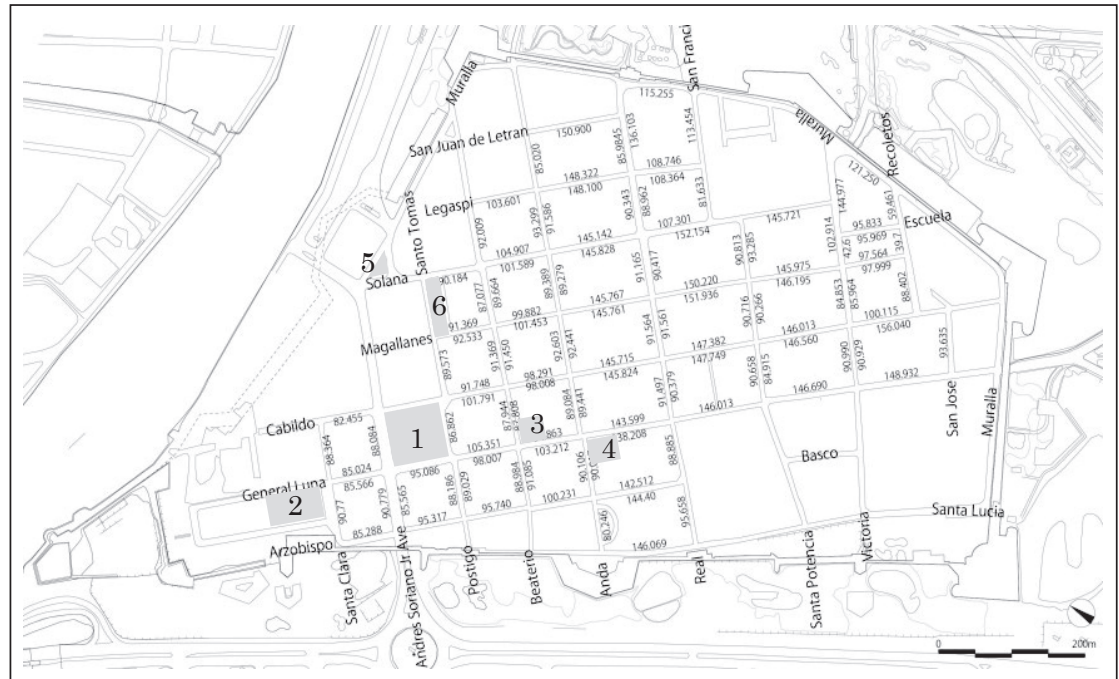

図 5 街路体系と街区寸法（単位：vara）と広場

1-Plaza Roma, 2-Plaza Moriones, 3-Plazuela San Agustín, 4-Plaza de Santa Isabel, 5-Plaza España, 6-Plaza Santo Tomás

除いて考えると長方形街区は東西南北 $90 \mathrm{vara} \times 150 \mathrm{vara}$ で計画さ れた可能性が高い。

ラ市立大学 (サン・イグナシオ教会跡), その他教会関連施設 (サン・ フアン・デ・ディオス San Juan de Dios）の跡地にラシウム大学が ある。アメリカ統治期にサント・ドミンゴ教会跡はアメリカ投資銀 行に, リコレクトス教会跡は出版社に代わっている。

イントラムロスには，プラサと呼ばれる広場は，ローマ広場（中 央広場）とモリオネス広場 Plaza Moriones がある。プラスエラ Plazuela と呼ばれる小規模広場は, San Agustín サン・アウグステ イン教会前, サンタ・イザベル Plaza de Santa Isabel, エスパーニ ヤ広場 Plaza España, サント・トマス Plaza Santo Tomás の 4 か 所ある (図 5)。

\section{4-2 街路体系}

GIS データから交差点における街路幅員を測ると， 6.33vara 16.98vara（1vara=0.8359m）であった。アメリカ期に拡 幅されたアンドレス・ソリアノ・ジュニア Andrés Soriano Jr. Ave 通りが最も広い。マニラの街路幅員は中央広場を中心に広く, 広場 から延びる 8 本の道路を中心に測ると, 6.33vara 12.56vara とな り, 平均は東西方向 9.5852 vara, 南北方向 8.9147vara となる。

イントラムロスは, 大きく 2 種類の街区（中央広場中心街区と南 の長方形街区）により構成されている。基本的に南北軸にその違い が見られ，東西軸はそれほど変化がない。

東西軸の規模は, 80.25vara 93.3vara であり, 平均 89.65vara であった。東西軸街区は 90vara で計画されたと考えられる。

中央広場を中心に都市建設を行うスペイン植民都市においては, 広場周辺街区がオリジナルに近いと考えられる。

旧サント・ドミンゴ教会周辺街区（広場の南東）は逆に変化して いない。規模は東西南北 $90 \mathrm{vara} \times 90 \mathrm{vara}$ であり, 1767 年以前の都 市図とも一致する。すなわち,この街区がオリジナルであると考える と,当初の街区は 90vara $\times 90$ vara で計画されたと言っていい。ヴィ ガンの街区構成も東西南北 $90 \mathrm{vara} \times 90 \mathrm{vara}$ であり, マニラと同じ である。

一方,長方形街区の南北の長さは, 138.21vara 156.04vara であり 平均は, 146.93vara となる。戦後に拡幅されたレアル Real 通りを

\section{4-3 街区分割}

都市図の中には宅地割を描いた資料がある(AGI,MP-FILIPINAS 229(1783), 図 2-7)。また宅地の形状が分かる俯瞰図としては, 口 八スの絵図がある（1715-1720,図 2-2)。建設初期の宅地割を示寸都 市図はないため, ロ八スの絵図を基準として, 1783 年の都市図, 現 在の 3 つの時期を間口, 奥行き, 面積について比較する注 ${ }^{10}$ ) (図 6 )。 比較可能な街区は 33 街区である。各街区の宅地数の変遷を一覧表 にまとめた（表 3 )。

ロハスの絵図（図6 (上)) を見ると,中央広場周辺街区では,縦横 2 分割する 4 分割が最も多い。また,分割されていない街区も多く, 建設初期の宅地割に近かったと考えられる。長方形街区については 様々なパターンがあるが 12 分割, 14 分割が多い。基本的には,まず, 東西（北西一南東）に 2 分割され,続いて南北（北東一南西）に宅地 分割を行うシステムである。前述のように，広場中心街区は 90vara $\times 90 v a r a ，$ 長方形街区は 90vara $\times 150$ vara で計画されたとすると， その奥行きの規模を 45vara とする分割が基本である。この分割線 は,現在も残されている（図6の太線）。

1783 年になるとさらに細分化されている。図 7 に街区の分割パタ ーンを示す。中央広場周辺街区では, 角地がさらに 2 4 分割され, 長方形街区も全体的に 2 7 分割されている。細分割された街区は, 特にパリアン門とサンタ・ルシア門を結んだレアル通りに多く, 中 心街路として商業施設等が立ち並んだと考えられる。広場など人々 が集まりやすい通りに面して分割が細かくなっている。1715 年 -1720 年から 1783 年にかけての宅地分割の変容は, ほとんど変化 がない宅地が多いが，変化が見られる宅地のうち角地では 35 の宅 地が, 2 分割 (19)，3 分割 (11)，4 分割 (4)， 7 分割 (1) 分割さ れ, 街区中央では 16 の宅地が, 2 分割 (15), 3 分割 (1), 分割さ れている。特に 2 分割が多い。

現在の街区構成を見ると（図6 (下)), 戦争による被害等により 以前の宅地割が基準となっているパターンは少なくなる。そして宅 地面積も小さくなり, より細分化された宅地割になっている。上述 
のように, 街区 20,25 は小規模住宅や併設住居が超過密密集してい る街区で，宅地割を判断できなかった。

人口増加等の理由から細分化が進行するのが一般的であるが，街 区番号 $21,23,25,30$ は 1783 年の段階で分割数が減少している。 特に街区 30 は減少が大きいが 1784 年に建設されたパリアンの市場 アルカイセリア・デ・サン・ホセが建設された街区である。

\section{5. まとめ}

スペイン植民都市の中で城壁を建設したのは 14 都市しかないが, その中でマニラは 11 番目の都市である。サント・ドミンゴ（イス パニョーラ島,1494 年) 注11)，ハバナ（1515 年） 注 ${ }^{12 ）}$ は,必ずしもグ リッド・パターンではないが, 整然としたグリッド・パターンの街区 割をしている。パナマ（1519 年）,ヴェラクラス（1519 年）のよう な先行事例はあるが, 1573 年のインディアス法 (「フェリペII 世の勅 令」）によって,植民都市計画が体系化される直前の事例である。す なわち,マニラは初期スペイン植民都市の 16 世紀を代表するひとつ のモデルと考えることができる。

本稿が明らかにしたことをまとめると以下のようになる。

(1)イントラムロスの街路体系は，建設初期から,以下を除いて,ほ とんど変化がない。街区が大きく変化したのは, スペイン統治時代 において,パリアンの市場を建設した際で, サンティアゴ要塞付近の 街区については無くなった街区がある。アメリカ統治時代において, パシグ川沿いの城壁が一部取り壊され, その近辺の街区が一部変化 している。

(2)初期の中央広場周辺の街区は, 街路の中心間は東西南北 100vara $\times 100$ vara（芯々）のグリッド，街区は東西南北 $90 \mathrm{vara} \times$ 90vara, 街路幅員は 10vara で計画された。この基準寸法は，ルソ ン島の世界遺産都市ヴィガンと同じである。中央広場もイ 100vara ×100vara（芯々）で計画されているが,これはインディアス法の規 定とは異なっている。

(3)マニラ・イントラムロスのユニークな点は,もうひとつ,長方形 街区が計画されていることである。長方形街区は, 東西南北 90vara ×150varaで計画されたと考えられる。

(4)建築物の建設年代から, 教会, 修道院, 市庁舎, 病院などの公 共の施設は中央広場周辺とイントラムロスの周辺街区に多く建設さ れた。イントラムロスの中央部, 南東側の長方形街区には個人の店 舗や住居が建設されていたと考えられ，この分布は現在も同じであ る。

(5)宅地割の奥行きは, 各街区を東西（北西一南東）に 2 分割した 45vara が基本である。この奥行きの分割線は現在も宅地割の境界線 として残されている。

以上,マニラ・イントラムロスの現在の空間構成は, 第二次世界大 戦によって大きく破壊されたにもかかわらず,初期スペイン植民都 市の空間構成をその骨格において今日に伝えるものと考えることが できる。

\section{参考文献}

1) Reed Robert R.: Colonial Manila -The Context of Hispanic Urbanism and Process of Morphogenesis-, University of California, 1978

2) Galván Guijo Javier: Arquitetura y Urbanismo de origen español en el

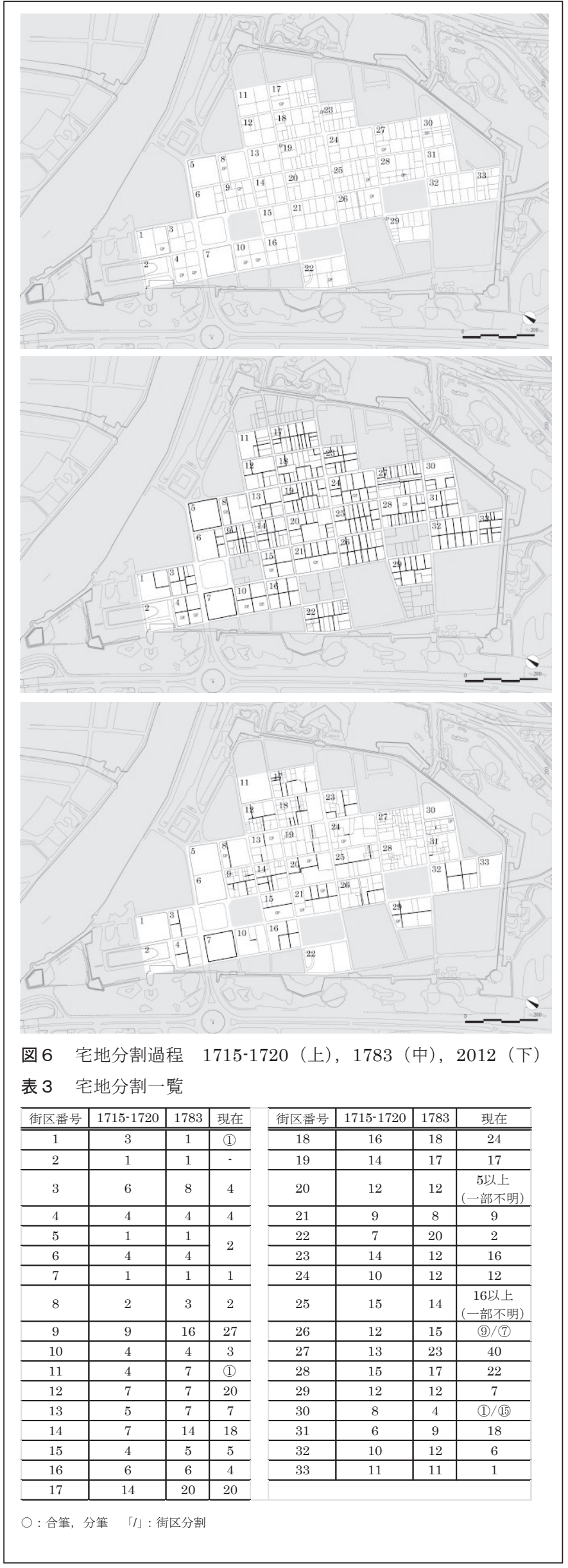




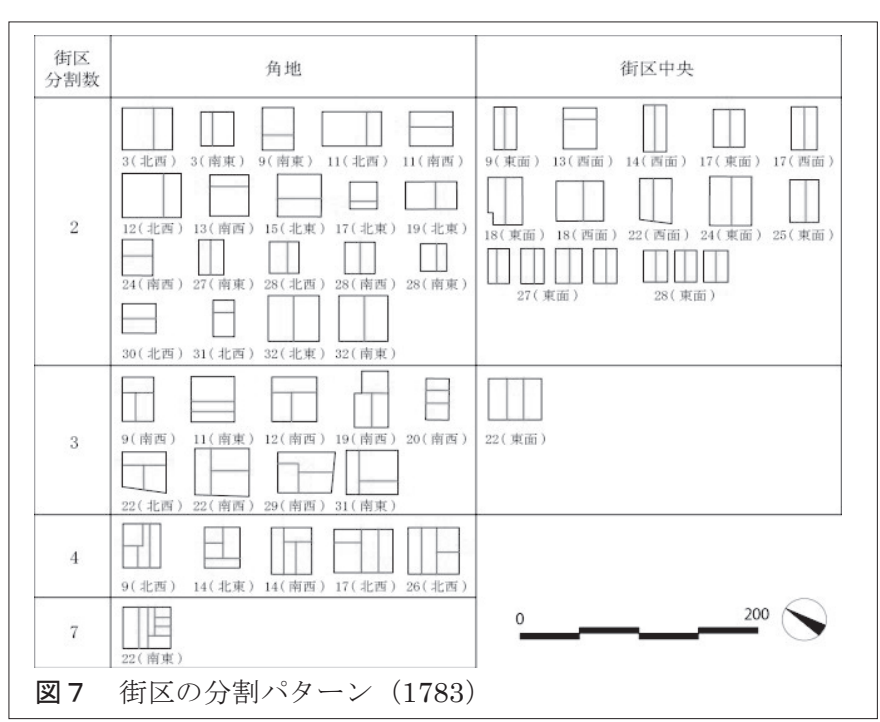

Pacífico Occidental, Universidad Politécnica de Madrid, 2004

3) Ortiz Armengol Pedro: Intramuros de Manila -De 1571 hasta su destrucción en 1945 -, Ediciones de Cultura Hispánica, Madrid, 1958

4) Gatbonton Esperanza B.: Bastión de San Diego, Intramuros Administration Ministry of Human Settlements, Manila, 1984

5) Z. Torres José Victor: A Walk Through Historic Intramuros, Intramuros Administration and Vibal Pub. House, Manila, 2005

6) Buzeta Manuel: Diccionario Geográfico, Estadístico, Histórico de las Islas Filipinas, Madrid, 1850

7) de Morga Antonio: Sucesos de las Islas Filipinas -1609-, Fondo de Cultura Economica, Mexico, 2007

8) Ang See Teresita: Tsinoy-The Story of the Chainese in Philippine Life-, Kaisa Para Sa Kaunlaran, Manila, 2005

9) L.E. Bauzo: Deficit Government, Mexico and the Philippine Situado -1606-1804-, Centre for East Asian Cultural Studies, 1981

10) William L. Schurtz: The Manila Galleon, Historical Conservation Society, New York, 1985

11) de Paz Ygunacio: Description of the Philippines island, Mexico Ca, 1658

12) Martínez de Zuñiga Joaquín: Estadismo de las Islas Filipinas o mis Viajes por este País, W. E. Retana, Madrid, 1893

13) Smith, M. T. Paske: The Japanese Trade and Residence in the Philippines, before and during the Spanish Occupation, Asiatic Society of Japan, Tokyo, 1914

14) Lico Gerard: Arkitekturang Filipino, a history of architecture and urbanism in the Philippines, UP Press, Quezon City, 2008

15)池端雪浦：日本占領下のフィリピン、岩波書店、1996

16) ニック・ホアキン：物語マニラの歷史、宮本靖介監訳、明石書店、2005

17)布野修司：近代世界システムと植民都市、京都大学学術出版会、2005

18) 岩生成一: 南洋日本町の研究、岩波書店、 1966

注

注 1) インディアス古文書館 AGI (Ministerio de Cultura. Archivo general de Indias)資料は，1.-Filipinas (1-273)，2.-Guatemala (1-345), 3.-Santo Domingo (1-916), 4.-Panamá(1-374), 5.-Mexico(1-772), 6.-Buenos Aires(1-304), 7.-Venezuela(1-286), 8.-Perú y Chile(1-270), 9.-Europa y África(1-125), 10-Florida y Lusiana(1-270), 11.-Otras (81-229), 12-Pasquines (1-16), 13-Varios (1-48), 14-América Generales(1-8), Exp.(3263)からなる 7152 枚である。

陸軍博物館 SHM/SGE の資料は, Tomo1-America en General Carpeta de Cartografia (S.H. 1983), Tomo 3-Mejico Volumen de Cartografia (SHM/SGE, 1990), Tomo 4-America Central Volumen de Cartografia (SHM/SGE, 1990), Tomo 5-Colombia Panama Venezuela Carpeta de Cartografia (SHM/SGE, 1980), Tomo 6-Venezuela Volumen de Cartografia (SHM/SGE, 1990), Tomo 7-Rio de la Plata Volumen de
Cartografia (SHM/SGE, 1992), Tomo 8-Peru Volumen de Cartografia (SHM/SGE, 1996), Tomo 9- Grandes y Pequenas Antillas 1 Volumen de Cartografia (GRANDES Y PEQUENAS ANTILLAS 1 VOLUMEN DE CARTOGRAFIA, 1999), Tomo 10-Filipinas Volumen de Cartografia (SHM/SGE, 1996), Carpeta 2-Estados Union y Canada Láminas (SHM/SGE, 1989)である。

注 2) J.R. ヒメネス ベルデホ，布野修司「セブ市（フィリピン）の都市形成 とその都市核の空間構成に関する考察」(『日本建築学会計画系論文集』 553,pp.1867-1874,2011)

注 3）脇田祥尚ほか「フィリピンにおけるスペイン統治期の都市計画:その 2 ヴィガンの都市空間構成」(『学術講演梗概集』F-1,pp.917-918,1998)，脇 田祥尚ほか「フィリピンにおけるスペイン統治期の都市計画:その 3 ヴィガ ンの都市構成」(『学術講演梗概集』F-1,pp.281-282,1999), 柳沢究ほか「フ イリピンにおけるスペイン統治期の都市計画:その 4 ヴィガンの街区構成」 (『学術講演梗概集』F-1,pp.283-284,1999), 山口潔子ほか「ヴィガン（イ ロコス，フィリピン）の街区構成に関する考察」(『日本建築学会計画系論 文集』553,pp.209-215,2002)，山口潔子ほか「ヴィガン（イロコス,フィリ ピン)における住宅の空間構成と街区分割」(『日本建築学会計画系論文集』 572,pp.1-7,2003), 飯田敏史「フィリピン・ヴィガンの都市空間構成とそ の変容に関する考察」(修士論文, 滋賀県立大学大学院, 2011 年 3 月)。

注 4) 1846 年 9 月 4 日- 1912 年 6 月 1 日, アメリカ人建築家であり, 都市計 画プランナー。シカゴで行われた世界博覧会のディレクターを務め, シカ ゴとワシントンの都市計画, フラットアイアンビルやニューヨークのユニ オン駅を設計している。

注 5) J.R ヒメネス・ベルデホ，布野修司，齋木崇人「スペイン植民都市図に 見る都市モデル類型に関する考察」(『日本建築学会計画系論文集』616, 92-97, 2007)

注 6)イントラムロスも周辺の町も街区は描かれず, 簡略化されて描かれた都 市図 5 枚を除く。

注 7）マイニラッド Maynilad とする文献もある。

注 8）マニラ・パリアンの創設は 1582 年である。パリアンの語源は, メキシ コ語説, イロコス語説, 中国語説があるが定かではない。メキシコでは, 東洋の産物の市場をパリアンと呼ぶ。もともとスペイン語のアルカイセリ ア，才なわち生系市場をパリアンといい，中国産の生系の市場を意味して いたと考えられる。中国語ではパリアンに「潤」あるいは「潤内」という 漢字をあてているが発音は異なる。マニラにおいては, 中国人居住地とす るが，実際，マニラの場合は生糸工場すなわちパリアンとすると創設当初 の記録に残されている。マニラなどの都市に舶載する商品の中で最も重要 なのは中国人の生糸であった。しかしながらパリアンの建設には，多くの 事情を抱えている。『モルガ フィリピン諸島誌 大航海時代叢書VII』([監］ 神吉敬三, 箭内健二 [ [発行]岩波書店 1966 年第 1 次, 1978 年第 2 次発 行）によれば, エスパーニャ人とシナ人の関係の悪化, 課税の問題などの 不正が相次ぎ，離れて住むように命じ，そこにシナ人のために店舗などが 建設されたが，そこで売られる商品には高価で売られた。つまり中国人隔 離居住地の創設すなわちパリアンである。

注 9）バハイ・ナ・バト bahay na bato（タガログ語で「石 bato の家 bahay」） とは, フィリピン都市で 19 世紀後半から 20 世紀初めに多く建てられた, 都市富裕層の住宅である。木骨石・煉瓦造の一階部（あるいは構造的には 木造であるがカーテン・ウォールとして石・煉瓦が用いられた一階部）と 木造の二階部で構成された二階居住型の住宅で, 格子状の引き戸に加工さ れたカピス Capaz 貝がはめ込まれた空が外観の特徴である。しかしながら 「バハイ・ナ・バト」というタガログ語の呼称が文面に現れ始めるのは 1880 年代に至ってからであり，これはアメリカ占領期に，スペイン時代の建築 と区別するために用いられ始めたと考えられている。つまり，これ以前は 名前や明確な時間区分を持った特定の住宅様式として認識されていなかっ た。その為に「バハイ・ナ・バト」の発生時を正確に決めるのは困難であ る。

注 10）教会がある街区，または台形街区は，間口，奥行きに一定の基準がな いため除く。街区分割を描いた図2-7から読み取れる街区分割を現在の GIS データに落とし込み,これをもとにロ八スの描いた街区分割を割り出した。

注 11）J. R. ヒメネス・ベルデホ, 布野修司「サント・ドミンゴ（ドミニカ共 和国）の都市形成と空間構成に関する考察察」(『日本建築学会計画系論文 集』648,pp. 385-393, 2010)

注 12）J. R. ヒメネス・ベルデホ, 布野修司，若松堅太郎「ハバナ旧市街の都 市形成と街路体系に関寸る考察」(『日本建築学会計画系論文集』675, 2012)

（2012年 3 月 12 日原稿受理，2012年 8 月 10 日採用決定） 